\title{
A review of Brazilian scientific output on crack - contributions to the political agenda
}

\author{
Marcelo Rasga Moreira ${ }^{1}$ \\ Fernando Manuel Bessa Fernandes ${ }^{1}$ \\ José Mendes Ribeiro ${ }^{1}$ \\ Thereza de Lamare Franco Neto ${ }^{1}$
}

\footnotetext{
${ }^{1}$ Departamento de Ciências Sociais, Escola Nacional de Saúde Pública, Fundação Oswaldo Cruz. Av. Leopoldo Bulhões 1480/926 Manguinhos. 21201-410 Rio de Janeiro RJ Brasil. rasga@ensp.fiocruz.br
}

\begin{abstract}
Object: scientific literature about crack abuse published in Brazilian journals indexed in SCIELO. Objective: systematic review of literature treating findings as a framework for agenda-setting orienting policy decision makers. Methodology: SCIELO online journals research since 02/06/2013 on tag crack as "key word searched" and in indexes as "research amplitude". An amount of 199 references were identified and their abstracts were analyzed getting to a final group of 59 articles specifically studying crack issues in Brazil. Analysis: institutional criteria (journal, subject area, and publishing time) and analytical categories created by the authors: "Social Risk", "Treatment", "Use/Abuse", "Profile", "Social Relations", and "Study". Results: crack use impact Brazilian journals since 2011; health field is prominent; articles about "Associated Risk" and "Treatment" prevail; SUS cannot face demand;investment improvement in CAP and harm reduction; therapeutic communities need to match with SUS standards; youngers, black people and poor express users profile; rave style use; repressive policies were not well succeeded; and multidisciplinary approach are necessary.

Key words Crack, Public policy, Agenda-setting
\end{abstract}




\section{Introduction}

In the 1990s, involved as they were with the complex and contradictory tasks that the re-democratization of Brazil demanded ${ }^{1}$, public governors and managers, and even leading intellectuals, came to a conclusion - for varying reasons - that consumption of crack was a phenomenon that was 'restricted' to São Paulo².

Two decades later, crack has been incorporated into the list of public problems suffered by Brazil's principal state capitals and metropolitan regions ${ }^{3}$. To make matters worse, the consumption of crack, although it happens in different 'use scenarios' ${ }^{34}$ has assumed unprecedented visibility as a result of a particular trend in the structure of cities: regions referred to as 'cracklands' (cracolândias), in which public streets are occupied by a large number of people who, suffering the effects of crack, group themselves around activities involving its sale and consumption.

This visibility inspires the indignation of sectors of the population, and of the media who, pressuring the authorities for immediate and final solutions, demand repressive and violent actions $^{5}$.

This escalation of pressure challenges logical and practical policies of a humanistic nature which: (i) have already become institutionalized, such as the culture of peace; of meeting the demands of consumers through public systems of social assistance and healthcare; and the replacement of institutionalization by humanized services existing within the logic of primary healthcare, and articulated with equipment that is appropriate to moments of crisis and containment of spending; and (ii) seek to institutionalize, as a policy of public safety based on the pacification of territories, the ability to go one step further than the 'war on drugs', and proposals for making consumption of drugs cease to be illegal.

The problems are of such a scale that the federal government, in an unprecedented move, allocated a considerable budget to a specific policy for one drug, the Crack, It's Possible to Win (Crack, é Possivel Vencer) Program³.

In view of the social importance of the issue, it is appropriate for researchers to produce analyses and evidence that contribute to the (re)formulation, implementation and execution of public programs and policies. This is a complex task, since the taking of decisions based on scientific evidence is not a widely disseminated practice in Brazil. It is encouraging, however, because Brazilian scientific production, especially in the field of health, has been boosted by research groups financed by the public power to analyze and assess policies, providing support and input for the activity of managers and producing actual results ${ }^{6}$.

In this context, this article seeks to review and analyze Brazilian scientific production on the question of crack, using the results of this traditional research strategy as a matrix for a political agenda that could help to orient managers in taking decisions in favor of policies that attenuate and overcome the problems that generate and are generated by the consumption and trade in the drug.

\section{Method}

The scientific output that is analyzed here is that which is published in Brazilian magazines and periodicals that are indexed in SciELO. Various reasons support this choice: (i) the subject of this article - the situation of crack in Brazil - has been dealt with almost exclusively by Brazilian output, with minimal international participation; (ii) this Brazilian production is concentrated in Brazilian magazines and periodicals; (iii) this also represents an effort to support scientific researchers and editors in debates on Brazilian scientific production and its dissemination; (iv) the analysis in this article did not consider Brazilian output published in international periodicals, and this indeed is one of this article's limitations - the limitation is attenuated by a preliminary study by the authors which indicates that international output, which is valuable, contains in large measure articles which differ little if at all in subject matter from the production investigated here; (v) SciELO indexes the principal Brazilian scientific magazines that may deal with crack, making it possible to state that the review is systematic; (vi) articles published in indexed periodicals are the principal means of publication and debate for academic production being as they are refined and objective versions of research reports, theses and dissertations ('grey literature'); and (vii) such articles generate results and reflections that are excellent input materials for production of recommendations for public policies.

A cutoff date of February 6, 2013 was adopted. An online search was made of articles on SciELO (www.scielo.br) using 'crack' as the term researched, and, as the scope of the search, all the indices. This resulted in 199 references, of which the summaries were analyzed. This analysis eliminated 140 references to such subjects as 
'cracking' of oil and oil products, and the study of physical-chemical reactions.

This left 59 references which in fact related to the issue of crack in Brazil. These were taken as the universe to be worked on, and reviewed and analyzed to meet the objective of this article.

The first step was creation of categories which, based on the objectives of each article (which were considered as criteria for inclusion/ exclusion in a given category), might serve as an organizational basis for the analysis of the 59 articles selected, and make it a practicable project.

The categories created were: (i) Public policies, related directly or indirectly to crack; (ii) Social relationships, namely the repercussions and effects of crack on relationships with family, community, friends and work; (iii) Use/consumption, referring to patterns and habits of use/consumption of the drug; (iv) Epidemiological profile, the characterization of groups/populations which are in some way linked to crack; (v) Treatment, referring to experiences and strategies for care and treatment of those who are dependent on crack; (vi) Associated risk, referring to risks and repercussions, for health and for life, of use/ consumption of crack; and (vii) Study, namely how the media and the academic world treat the question of crack.

Once classified, the articles were studied for the purposes of a review to highlight their principal concepts, reflections and results, seeking an analysis of these elements that would be able to produce an agenda able to orient the process of decision.

\section{Analysis of the articles}

\section{Institutional results: Periodicals, areas of knowledge, subject groups, and dates of publication}

Table 1 illustrates that, of the 59 articles selected, only one was published in a periodical in the field of Social Sciences. The other 58 all relate to the field of Health, making that the dominant subject area:

Under 'subject of the article' it is seen that $48 \%$ of the items relate to 'Associated risk' (17 items) and 'Treatment' (11); and that a second group, 'Social relationships' (9) 'Epidemiological profile' (8) and 'Use/consumption' (7) make up $40 \%$ of the articles. A third group contains the theme areas 'Study' (4) and 'Public policy' (3), making up the remaining $12 \%$ of the total.

By year of publication, Chart 1 shows that only four of the articles date from the late 1990s, and that there is a consistent increase in the number of publications only as from 2008:

We look at the categories that we have created for classifying the articles, without seeking to be mutually exclusive, and this leads us to the following observations. The aim is not to: (i) seek points of consensus or dissension between the articles; (ii) quantify information; (iii) report a hierarchy of subjects approached or dealt with by larger or smaller numbers of references in the articles; (iv) describe or discuss any of the selected articles individually; nor (v) exhaust all the possibilities of review of, or reflection about, the articles.

The intention of the analysis is to identify concepts, criticisms, results, debates, reflections and evidences, organizing them and presenting them in such a way as to produce a list of systematized items of information that can contribute to the production of a political agenda that can orient the managers of the decision-making process.

\section{Public policies}

Chart 2 illustrates the principal discussions that the authors engaged in on the subject of 'public policies' directly and indirectly related to the question of crack:

Although they diversify the policies that they deal with, the articles tend to discuss them from the basis of two aspects (which are not necessarily articulated and/or present at the same time in all the articles): Characteristics and interfaces 'of' and 'with' the Crack, It's Possible to Win program, and the relationship with international policies for combating drugs.

The articles explain that a significant portion of policies adopted, worldwide, was oriented by the doctrine of the 'War on Drugs', financed by the United States. When these policies are backed and accepted by international treaties, the signatories incorporate the proposals of those policies into their local legal framework, and in many cases this can contradict the focus or directions that a particular nation has sought to give to the issue of drugs. According to the articles, this happens in Brazil.

As to the Crack, It's Possible to Win program, the articles put it in the context either of the international scenario of policies aiming to combat drugs, or in the context of the Brazilian psychiatric reform and the possibilities and difficulties of Brazil's Single Health System (Sistema Único de Saúde, or SUS).

When the focus is on the SUS, a debate that stands out is on limits and difficulties for dealing 
Chart 1. Distribution of the 59 articles selected, by periodical, and the number of articles published by each; subject area of the publication; subject of the article; and year of publication.

\begin{tabular}{|c|c|c|c|}
\hline Periodical & $\begin{array}{l}\text { Number } \\
\text { of articles }\end{array}$ & $\begin{array}{c}\text { Area } \\
\text { of publication }\end{array}$ & $\begin{array}{c}\text { Subject } \\
\text { of the article }\end{array}$ \\
\hline $\begin{array}{l}\text { Revista Brasileira de Psiquiatria } \\
\text { (Brazilian Psychiatric Review) }\end{array}$ & 7 & Psychiatry/psychology & $\begin{array}{l}\text { - Profile: } 1 \\
\text { - Associated risk: } 5 \\
\text { - Use/Consumption: } 1\end{array}$ \\
\hline $\begin{array}{l}\text { Jornal Brasileiro de Psiquiatria } \\
\text { (Brazilian Journal of Psychiatry) }\end{array}$ & 7 & Psychiatry/psychology & $\begin{array}{l}\text { - Profile: } 1 \\
\text { - Social relations: } 1 \\
\text { - Associated risk: } 2 \\
\text { - Treatment: } 3\end{array}$ \\
\hline $\begin{array}{l}\text { Revista de Saúde Pública } \\
\text { (Public Health Magazine) }\end{array}$ & 6 & Public health & $\begin{array}{l}\text { - Profile: } 1 \\
\text { - Associated risk: } 1 \\
\text { - Treatment: } 1 \\
\text { - Use/Consumption: } 3\end{array}$ \\
\hline $\begin{array}{l}\text { Ciência \& Saúde Coletiva } \\
\text { (Science and Collective Health) }\end{array}$ & 5 & Public health & $\begin{array}{l}\text { - Study: } 1 \\
\text { - Public policy: } 2 \\
\text { - Social relations: } 2\end{array}$ \\
\hline $\begin{array}{l}\text { Cadernos de Saúde Pública } \\
\text { (Public Health Studies) }\end{array}$ & 4 & Public health & $\begin{array}{l}\text { - Study: } 1 \\
\text { - Profile: } 2 \\
\text { - Public policy: } 1\end{array}$ \\
\hline $\begin{array}{l}\text { Revista de Psiquiatria do Rio Grande do Sul } \\
\text { (Psychiatry Review of Rio Grande do Sul) }\end{array}$ & 4 & Psychiatry/psychology & $\begin{array}{l}\text { - Profile: } 1 \\
\text { - Social relations: } 1 \\
\text { - Treatment: } 2\end{array}$ \\
\hline $\begin{array}{l}\text { Revista Latino-americana de Enfermagem } \\
\text { (Latin-American Nursing Review) }\end{array}$ & 4 & Nursing & $\begin{array}{l}\text { - Profile: } 1 \\
\text { - Social relations: } 3 \text {; }\end{array}$ \\
\hline $\begin{array}{l}\text { Revista da Asociação Médica Brasileira } \\
\text { (Brazilian Medical Association Review) }\end{array}$ & 3 & Medicine & $\begin{array}{l}\text { - Associated risk: } 1 \\
\text { - Use/Consumption: } 2\end{array}$ \\
\hline $\begin{array}{l}\text { Estudos de Psicologia } \\
\text { (Psychology Studies) }\end{array}$ & 2 & Psychiatry/psychology & $\begin{array}{l}\text { - Study: } 1 \\
\text { - Treatment: } 1\end{array}$ \\
\hline $\begin{array}{l}\text { Revista de Psiquiatria Clínica } \\
\text { (Clinical Psychiatry Review) }\end{array}$ & 2 & Psychiatry/psychology & $\begin{array}{l}\text { - Social relations: } 1 \\
\text { - Associated risk: } 1\end{array}$ \\
\hline $\begin{array}{l}\text { Revista da Soc. Brasileira de Fonoaudiologia } \\
\text { (Braz. Speech \& Auditive Therapy Soc. Review) }\end{array}$ & 2 & $\begin{array}{l}\text { Speech \& Auditive } \\
\text { Therapy }\end{array}$ & - Associated risk: 2 \\
\hline Trends in Psychiatry and Psychotherapy & 1 & Psychiatry/psychology & - Treatment 1 \\
\hline
\end{tabular}

it continue

with the situation of crack. The considerations and criticisms are put into context in two wider and more complex debates: the directions taken by the Brazilian Psychiatric Reform, and therapeutical communities.

In relation to the psychiatric reform, the following question is raised:
Could it be [...] that the movement of the Psychiatric Reform is being consumed by the democratizing force of managements of municipalities, states and the federal government, because some of its more energetic and powerful militants have assumed significant public functions within the apparatus of the State? By incorporating classical 
Chart 1. continuation

\begin{tabular}{|c|c|c|c|}
\hline Periodical & $\begin{array}{l}\text { Number } \\
\text { of articles }\end{array}$ & $\begin{array}{c}\text { Area } \\
\text { of publication }\end{array}$ & $\begin{array}{c}\text { Subject } \\
\text { of the article }\end{array}$ \\
\hline Clinics & 1 & Medicine & - Associated risk: 1 \\
\hline $\begin{array}{l}\text { Jornal Brasileiro de Pneumologia } \\
\text { (Brazilian Pneumology Journal) }\end{array}$ & 1 & Medicine & - Associated risk: 1 \\
\hline $\begin{array}{l}\text { Psicologia: teoria e Pesquisa } \\
\text { (Psychology: Theory and Research) }\end{array}$ & 1 & Psychiatry/psychology & - Associated risk: 1 \\
\hline $\begin{array}{l}\text { Psicologia: ciência e profissão } \\
\text { (Psychology: Science and Profession) }\end{array}$ & 1 & Psychiatry/psychology & - Study: 1 \\
\hline $\begin{array}{l}\text { Revista Brasileira de Enfermagem } \\
\text { (Brazilian Nursing Review) }\end{array}$ & 1 & Nursing & - Profile: 1 \\
\hline $\begin{array}{l}\text { Revista Brasileira de Terapia Intensiva } \\
\text { (Brazilian Intensive Therapy Review) }\end{array}$ & 1 & Medicine & - Associated risk: 1 \\
\hline $\begin{array}{l}\text { Revista do Hospital das Clínicas } \\
\text { (Hospital das Clínicas Magazine) }\end{array}$ & 1 & Medicine & - Use/Consumption: 1 \\
\hline Brazilian Journal of Infectious Diseases & 1 & Medicine & - Associated risk: 1 \\
\hline $\begin{array}{l}\text { Revista Brasileira de Medicina do Esporte } \\
\text { (Brazilian Sport Medicine Review) }\end{array}$ & 1 & Medicine & - Treatment: 1 \\
\hline $\begin{array}{l}\text { Revista Gaúcha de Enfermagem } \\
\text { (Nursing Magazine of Rio Grande do Sul ) }\end{array}$ & 1 & Nursing & - Treatment: 1 \\
\hline $\begin{array}{l}\text { Revista da Escola da Enfermagem da USP } \\
\text { (São Paulo University Nursing School Review) }\end{array}$ & 1 & Nursing & - Treatment: 1 \\
\hline Vibrant (Virtual Brazilian Anthropology) & 1 & Anthropology & - Social relations: 1 \\
\hline
\end{tabular}

Source: Compilation by authors.

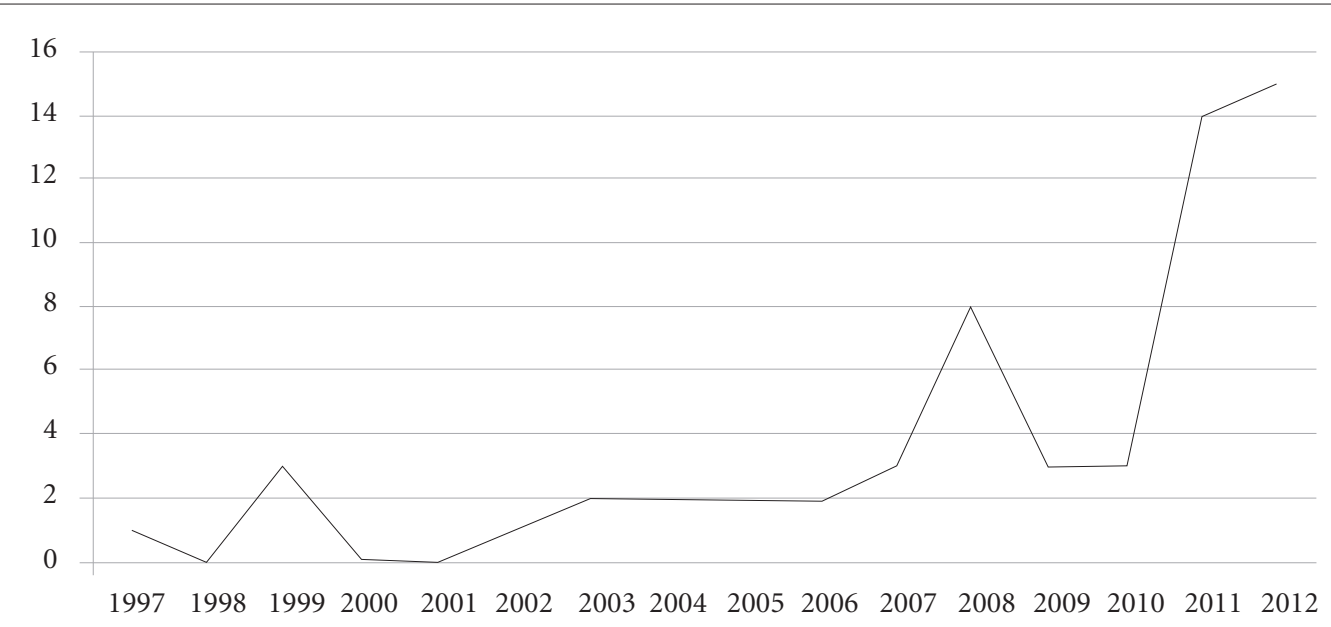

Graph 1. Distribution of the 59 articles selected. 
Chart 2. Public policies: Principal situations dealt with by the articles selected.

\begin{tabular}{|c|}
\hline Public policies \\
\hline $\begin{array}{c}\text { General aspects } \\
\text { - Brazilian adhesion to international policies based on the 'war on drugs' generates obligations that limit } \\
\text { Brazilian policies; } \\
\text { - Precarious cooperation between sectors: Policies implemented without coordination of the sectors responsible } \\
\text { cause negative effects, especially in consumption locations. The principal example is the lack of coordination } \\
\text { between social assistance, health and public policy. }\end{array}$ \\
\hline $\begin{array}{c}\text { 'Crack - It's Possible To Win': } \\
\text { - Accept and assume the need for Inter-sector coordination and action: } \\
\text { - States and municipalities will have difficulties in proposing projects and programs to fit in with the federal } \\
\text { policy because they do not have a tradition of mental health policy; } \\
\text { - Resistance of managers and professionals of general hospitals in creating/making available beds for consumers } \\
\text { of crack in situations not served by the CAPS-AD; } \\
\text { - Support houses for children and adolescents that are consumers of crack depend on equipment and } \\
\text { professionals with knowledge that the municipalities do not have; } \\
\text { - Art and culture centers offer activities that generate productions that have low added value and are unlikely to } \\
\text { result in placement in the work market. There is a need for projects for generation of income and interaction } \\
\text { with the market; }\end{array}$ \\
\hline $\begin{array}{l}\text { Health policies: } \\
\text { - The specialized services, although they have been and are expanding, do not exist in the needed quantity, they } \\
\text { offer few options for treatment of psychotic attacks and crises, they are not continuous (provided every day, } \\
\text { over long periods), they are not adequately distributed throughout the country, and they are managed by } \\
\text { and employ professionals who do not have the training and knowledge to deal with the habits and lifestyle of } \\
\text { crack consumers; } \\
\text { - Mental health is not a priority for states and municipalities; } \\
\text { - Loss of initiative-taking and positioning in the Damage Reduction Policy; } \\
\text { based on the territory and on de-institutionalization; } \\
\text { - Low National Coverage of ESF (Family Health Strategy) prejudices development of mental health policy } \\
\text { - Standoffs between supporters of the Brazilian Health Reform who took over management positions, and those } \\
\text { who remained in the services or in academic work arguing for the original bases of the Reform; } \\
\text { - Standoffs on therapy options, especially with those who argue for actions of a religious type; } \\
\text { - The appeal that the proposals of the Therapeutic Communities have for the general public. }\end{array}$ \\
\hline $\begin{array}{l}\text { Social assistance policies: } \\
\text { - Low nationwide coverage of CRAS and CRES, little integration with PSF and CAPS. }\end{array}$ \\
\hline $\begin{array}{c}\text { Public Safety Policies: } \\
\text { - Repression policies are characterized by prejudice and violation of rights: Homeless people, consumers and } \\
\text { drug dealers treated in the same way, with violence and violations of rights; 'hygienist' attitude; increase of the } \\
\text { social stigmas, principally against the homeless; } \\
\text { - Inefficiency: Consumers/dealers of crack merely move to another street or wait for the police to leave and } \\
\text { return to the same street. }\end{array}$ \\
\hline
\end{tabular}

Source: www.scielo.br. Compilation: Authors

rallying-cries [...] such as the closing of the insane asylums and increased accessibility to community mental healthcare, have the democratic governments emptied it of its most mobilizing slogans?[...] Are the reforming militants consuming each other in fratricidal battles [...]? ${ }^{7}$

The kernel of the arguments centers on the recognition of the expansions of the Psycho-social Care Centers (Centros de Atenção Psicossocial, or CAPS), the Therapeutical Rehabilitation Ser- vices, and others that focus on proximity to the community and make it possible for patients to be released from institutions, one of the prerequisites of the Reform.

At the same time, the criticism is raised that such services: since they do not exist in the adequate quantity and with the appropriate number of places available; because they are unequally distributed throughout Brazil; because they are not integrated with the territory and with a re- 
ferral network; because they do not work all day; because their degree of integration with the policy of damage reduction is low; and because they do not have managers and professionals with the right degree of training and experience to deal with the patients - have limited capacity to meet the demands that arise, especially in the event of psychotic crises and attacks, and that it is this type of situation that gives rise to a demand for users of crack to be hospitalized.

It is in this context that the articles identify relationships between the Crack, It's Possible to Win program and the SUS, and begin to argue for a policy of mental health based on the proposal of the psychiatric reform. The article by Andrade ${ }^{8}$ illustrates this situation, pointing to aspects of the federal policy on crack that are directly related to improvement of healthcare: creation of beds in general and psychiatric hospitals for people who abuse or are dependent on alcohol, crack or other drugs; implementation, in cities with a population of more than 500,000, of day-care centers for children, adolescents and young people using drugs in conditions of extreme vulnerability; and implementation of art, culture and income-generation centers in the network of care for users of alcohol and other drugs.

An understanding emerges that the therapeutic communities arise as a treatment option only because, in some way, they meet the demands for hospitalization. In this debate, an important point is that therapeutic communities do not fit under any of the institutional directives of the SUS.

Bastos $^{9}$ indicates the complexity of this debate, in that the parties debating sometimes have recourse to the inscrutable nature of the products of the unconscious, and sometimes to the formulations of various religious denominations, forgetting the frameworks of the republic and of democracy and that, as a result, critical dialog with Reason is not a luxury, but a republican necessity.

Thinking in an inter-sector manner, an important aspect to be highlighted is the anti-harmonic and counterproductive effect that occurs when public policies on the question of drugs are not coordinated.

This lack of articulation is analyzed from the starting point of the negative effect which a police action including direct combat of drug dealers in communities can produce if it is not articulated with the health services - putting at risk not only the lives of professionals and citizens, but the work that the services have succeeded in building with the drug users.
Also in this category are the criticisms of 'Operation Clean-up ${ }^{10}$, an operation by São Paulo state focusing on the district of Luz, in São Paulo city, in 2005.According to the authors, not only did this policy not achieve results, but it violated rights, practiced violence, reinforced stigmas and obstructed the social assistance and health policies that were operating at the location.

The scenarios that are outlined by the articles on public policies, especially those that refer to public safety, go deeper and are better understood when one studies the articles in the 'Social relationships' category.

\section{Social relationships}

Consumption of crack in Brazil started and grew in the late 1980s and early 1990s, in and from the city of São Paulo ${ }^{10}$ :

Crack has been popular in the United States since the 1980s, and emerged in Brazil in 1988, in some of the poorer outlying areas of São Paulo city. In 1991 there was already an intense demand for the drug in the central region of the city, especially in the district of Luz; and in 1993 its consumption had grown to a very large scale. It was reported that use of crack had increased from $5.2 \%$ of total drug consumption in the country, in 1989, to 65.1\%, according to a study in 1995-1997 - making crack and cocaine the principal drugs consumed in the city.

The articles characterize the introduction and growth of crack in São Paulo in terms of 'market relationships', describing the actions of the dealers in language typical of decisions in the corporate world:

Initially, since [crack] was unknown, to facilitate its presentation to users and adoption by them, the dealers exhausted the supplies of other drugs at the distribution points, making only crack available. Having no alternatives, users were thus obliged to choose crack and adopt it [...] initial$l y$, crack was converted from cocaine chlorohydrate [powder] by the user himself, creating a 'shell'. Subsequently, since production had been concentrated in the hands of the dealer [...], it began to be produced in the form of 'rocks', which were attractive for their low unit cost, initially causing the false impression that it was a cheaper drug than others [...] The allusion to an organization underlying the local dealers indicates an even greater complexity, inherent to the large dealing networks, with their internal arms and helpers within official structures. However, in parallel to that organization there are innumerable micro-dealers who sell drugs to provide their subsistence, or to guarantee their supply 
of crack, or both, and these are more visible and also more exposed to the consequences of this illegal practice $^{11}$.

Although this logic emphasizes market relations, it appears to be directed toward dealers and the trade in particular, since those who use the drug are not described as 'consumers', but 'users'. The sale and consumption of crack are portrayed as happening in public places, in the light of day, bringing together hundreds of people who spread out over streets and alleys. This is the phenomenon that led to coining of the term 'crackland', which, according to the articles, is ambiguous and prejudiced.

In discussing the term 'crackland', Raupp and Adorno ${ }^{4}$ emphasize its dimension of a 'force field' - a group of relationships that includes the dispute of interests between users, dealers, residents, local traders and the public authorities. Going beyond the physical dimensions, they aim to understand the social, economic and political relationships involved, highlighting that the repressive character of the public security policies represented the authorities' interest in removing the trade and the consumption of crack from a central and historic region (of great financial value) of São Paulo city.

Frúgolli Jr and Spaggiari ${ }^{12}$ find that the term is more used by the media than by the population that lives and works in the places where crack is consumed and sold. They say it is used to locate both a region of sale and consumption and also a region of dealing - reflected in the term having been adopted as a place-name for the district of Luz in São Paulo city.

Raupp and Adorno $^{10}$ indicate that the presence, in a 'crackland', of children who live in the street is influenced by the 'circles of sociability and socialization' that they live in, which put them in direct contact with the use of drugs. They say that the chemical properties of crack are perfectly adapted to a lifestyle typical of those circles - in which one lives for the instantaneous pleasure of the moment-creating a synergy that becomes visible in the compulsion to smoke one 'rock' of crack after another.

This participation of children in 'cracklands' raises an analogy with family relations:

[...] In general, the role of the family has three aspects. The first is the role of the family as a center, providing social protection, as a result of which its active and participant nature is present in processes of change; the second is as something that can, paradoxically, either create or destroy, give identity to or disintegrate the individual that is in the pro- cess of formation; and the third is its importance in promoting and maintaining health among its members ${ }^{13}$.

Although most of the articles point to the first and the third of these aspects of the family, a study of chemically dependent adolescents in treatment at the psychiatric unit of the University Hospital of Western Paraná ${ }^{14}$ identifies what the above authors classify as the second aspect, considering the family as a factor of influence for the consumption of alcohol and cigarettes.

The authors referred to above incorporate cultural relationships into their analyses by pointing to family interactions, initiation and acceptance rituals, and lifestyles. Only one article centers on cultural relationships, studying the messages on drugs conveyed by rap music entertainment. This genre aims, they say:

[...] to warn young people about possible dangerous situations and create a common identity among them that can serve as protection. It also seeks to make the young person aware of mechanisms for survival in the poor districts of cities. It creates information that operates as a counterpart to the ideology promoted in the media - the importance of economic status and the means of achieving it-principally the medium of television, which is considered to be one of the biggest villains in forming the mentalities and the imaginative world of young people [...]. Lyrics assume two possibilities of response to the adverse conditions of poor city districts: succumb, and die from violence, or from drugs; or adapt oneself and face the 'traps of society [...]': crack and cocaine "are substances that bring disaster upon the individual and which really do cause dependency and alienation. Rap appears to support and reinforce the view - which is mistaken from the scientific point of view - that there are 'light' drugs, such as marijuana and alcohol, and 'heavy' drugs: crack and cocaine. The 'light and natural' drugs are associated with poor districts that live in peace, and the 'heavy and chemical' drugs are associated with poor districts that are dangerous ${ }^{15}$.

Nardi et al. ${ }^{16}$ include the school among the protection mechanisms: their investigation shows lower crime rates among adolescents who are studying.

Silva Júnior and Monteiro ${ }^{17}$ discuss crack and mortality:

Crack and death are intertwined, in the daily life of these users, orienting their lives, determining values, binding and linking their existences [...]. Death is understood as transcendence, seen as a passage and not an ending [...] a way of living 


\section{Use/Consumption}

Ramos's reflection takes us to the category 'Use/Consumption', since he considers that the user of crack needs to go through a near-death to keep himself alive, because he only experiences the sensation of being alive [...] through the nondeath. Hence the need to consume the drug multiple times.

This need is influenced by other elements, especially the effect of the drug. Associated with orgiastic consumption, the typical image of 'crackland' seems to strengthen the concept that the user of crack, more than any other drug, undergoes inevitable loss of his relationships with family, friends, school and work, which only strengthens his involvement with the drug. Hence the emphasis on the idea that to care for the health of users it is necessary to remove them from the streets, to isolated locations, where they can be 're-introduced to social relationships'.

Seleghim et al. ${ }^{13}$, taking a contrary direction to this common view, point to behaviors that have been reported over a longer period in the international literature:

The culture of the use of crack has undergone changes as to the pattern of use and, although most users do it compulsively, cases of controlled use [...] have been observed... It is now possible to find people who have been users for more than five years, with an associated use pattern [...]. These individuals have succeeded in maintaining their employment and family links.

Ribeiro et al. ${ }^{19}$ also reached similar findings, reporting that, in follow-ups with users of crack, the average time of consumption was 11.5 years. Ribeiro et al. ${ }^{20}$ show a considerable fall in the number of deaths of crack users, indicating that the risk of death from overdose is very low, and that the principal risk is of homicides.

Oliveira and $\mathrm{Nappo}^{21}$ considered that the compulsive pattern, though dominant, is not the only one - suggesting the existence of a controlled pattern [...] with rational and non-daily use of crack. This would tend to soften the previous stereotype of the crack user as someone irresponsible, non-productive and aggressive.
They associate the compulsive pattern with criminal activity (drug dealing, robbery...), and sex, as means of raising money to buy the drug. They perceive these practices as having a relationship with the immediate and very rapid effects of crack, which generate craving and the urgent need for more consumption. This urgency leads them also to consume other drugs, such as marijuana, and also to take cocaine in other ways, sometimes to strengthen and sometimes to weaken the effects of crack.

For those who follow a controlled pattern, on the other hand, consumption is not daily, it does not involve unlawful activities and it is reconciled with pre-existing social activities (work, school...), protecting the user from being marginalized by society.

Dias et al. ${ }^{22}$ indicate that the controlled pattern - longevity of consumption - tends to be stimulated by high availability and profitability of crack, and ease of access to it. They report that crack has undergone changes, such as a change of color, consistency, effect and size, which results in preparations that have lower addictive potential and can be subdivided into smaller portions, resulting in lower cost and greater dissemination.

Sanchez and $\mathrm{Nappo}^{23}$, looking for patterns in the sequence of drugs consumed by a user prior to using crack, conclude that the patterns that are found seem to be associated with external decisions (availability, interference by dealers, prevention campaigns, the historic period when they began consumption, group pressures, and others), than a causal relationship between the various drugs that make up that trajectory.

There are studies ${ }^{24-26}$ which, although they focus on the use/consumption of crack, build up profiles - bringing us to our category of article entitled 'Epidemiological profile'.

\section{Epidemiological profiles}

Chart 3 shows the articles in this category. Similar characteristics are seen in the profile of users, in particular predominance of male young people and young adults, with a low level of schooling, and without regular work, or unemployed.

Although these articles are extremely important, their focal characteristic is a factor that limits understanding about who the users of crack are, and what are their desires, anxieties, needs and motives. The articles that look at the treatment of crack users are also topical and focused and make some contribution to this understanding. 
Chart 3. Profile of the principal characteristics dealt with by the articles selected.

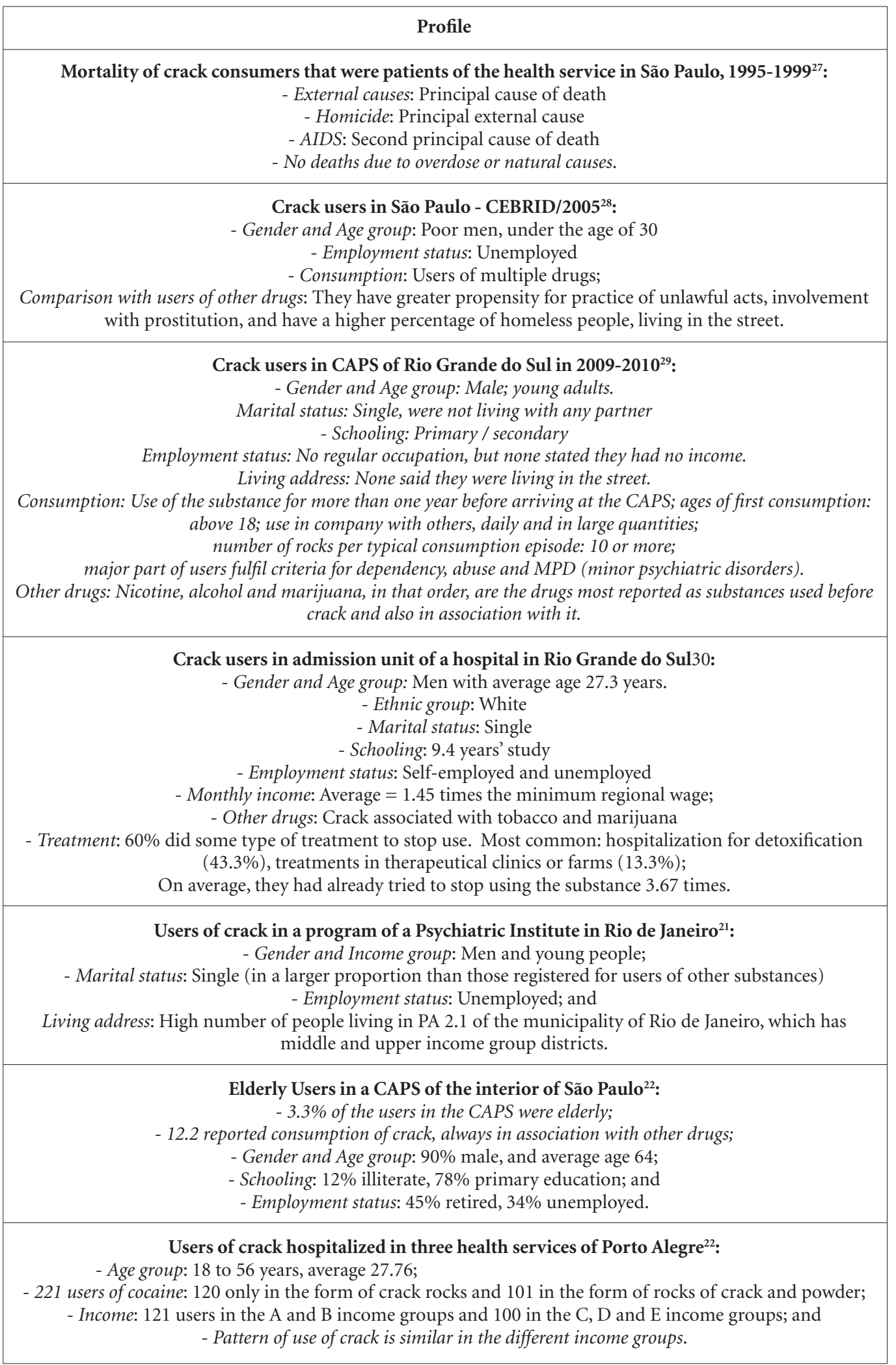

Sources: Compilation by authors. 


\section{Treatment}

A treatment that involves advice by telephone for young crack users was dealt with by Bisch et al. ${ }^{27}$. It is the Brief Motivational Intervention (Intervenção Breve Motivacional, or IBM) technique, used with telephone sessions. According to the authors - who state that, at the end of the sixth month of their monitoring, 65\% of the young people served had stopped consuming crack this treatment has the advantages that (a) it can applied by any qualified and trained professional, and (b) it allows the crack user to receive the service in his or her own home.

Success in treatment of a crack user necessarily involves success in treatment of the phenomenon known as craving, a strong impulse to use a substance, which is the main factor in the development of compulsive use, drug dependency and relapses after a period of abstinence ${ }^{28,29}$. Chaves et al. ${ }^{30}$ explain that the pattern of intense, continuous and repetitive ('binge') consumption of crack is caused by this craving.

Balbinot et al. ${ }^{31}$ state that since no pharmaceutical has yet been identified that acts on the multiple receptors of crack, the treatment of craving is mainly by non-pharmacological methods, in particular cognitive behavioral therapy.

Zeni and Araújo ${ }^{32}$ believe that for success in treating 'craving' it is essential to strengthen the user's ability to live through it and avoid consumption. Studying the application of the technique of RR - Respiratory Relaxation - the authors classify it as an important strategy for preventing relapse, which can be taught in the clinical environment and applied at anytime, anywhere.

Araújo et al. ${ }^{40}$ studied the use of cue exposure treatment (CET) and coping skills training (CS) as adjuvant therapies in the treatment of crack cocaine dependents and consider that the good results justify expansion of studies on the efficacy of these techniques. Good results were also reported by authors who studied techniques such as Iowa Gambling Task ${ }^{41}$ and cooperative games ${ }^{42}$, and who worked with spirituality workshops ${ }^{43}$.

Adopting a controversial position, Kessler and Pechansky ${ }^{44}$ considered that:

[...] the strategy that would seem to show the greatest result involves a long-term treatment structure which includes an initial admission to a psychiatric environment in a general hospital, and extends to a model of care based on closed therapeutic communities or with a high degree of intensity of treatment, also for long periods - frequently six months to one year.
Separately from the question of treatment, all the authors indicate that crack is related to a lowering of the user's values and self-esteem, which has a direct repercussion on risk behaviors for obtaining and consuming the drug.

\section{Associated risk}

The articles placed in this category also identify that, to deal with the craving, many users exchange the drug - or the money needed to buy it - for sex, exposing themselves to the risk of STDs and AIDS, unwanted pregnancy and sexual violence ${ }^{45-51}$.

Other risks identified: Neuropsychological alterations such as verbal fluency, visual memory, attention, verbal memory, learning capacity and executive functions ${ }^{52}$; cardiovascular complications ${ }^{53}$; lung complications ${ }^{54}$; effects on ear, nose and throat functions $s^{55}$, but not the auditory function ${ }^{56}$; psychiatric disorders ${ }^{57}$; trauma and stress $^{58}$ and cerebral vasculitis ${ }^{59}$.There are risks, also, for newborn babies whose mothers are crack users, especially for the start of oral feeding ${ }^{60}$.

A study that sought to associate the use of aluminum cans as a receptacle for consumption of crack and the level of this metal in the blood did not find significant alterations, but indicated the need for more studies, especially among those who have consumed the drug for a longer time ${ }^{61}$.

\section{Study}

Concluding this section of this work, an analysis of the four articles in the 'Study' category points to a primary characteristic: The three articles that study the media's treatment of crack find the main tone of media coverage to be criminalization, and reinforcement of its stigmas.

Romanini and Roso ${ }^{62}$, studying the newspaper Zero Hora, of Rio Grande do Sul, highlight that it leads the reader to conclude that every crack user sooner or later becomes a criminal. The relationship between crack and violence comes to be regarded as natural, strengthening attitudes of exclusion, that is to say, attitudes of domination. Similarly, Santos et al. ${ }^{63}$, studying coverage by the leading newspapers of Pernambuco State, conclude that the meanings constructed by the press on the subject of crack appear to anchor on the idea of madness and violence.

On the one hand, the user is presented as someone who is outside the law, outside 'normality' [...].On the other hand, as well as a health problem, crack appears as a matter for the police. What remains for the crack consumer, even if implicitly, is the label of criminal, diseased or sinner. 
The third article ${ }^{64}$ shows that although there is no scientific evidence of something like an 'epidemic' of crack in Brazil, the use of the term by the media has even affected researchers, who have begun using the term.

The last article in this category has a similar objective to this present work, proposing, however, that an incursion should be made into Brazilian dissertations and theses - the so-called 'grey literature. In this article, Rodrigues et al. ${ }^{65}$ point, as we do here, to the need for the human and social sciences to accompany the efforts of the health sciences:

The scientific output of master's degree and doctorate courses in Brazil has not accompanied the generalized concern [...]. The great majority of the subjects that are being investigated are in the fields of healthcare, treatment and recovery [...]. There is a need for other areas of knowledge (for example, the human, social and applied sciences) to come to grips, as priority, with the problems that involve the subject of crack, with a view to contributing to results that have already been produced, especially by the health sciences. At present, the results seem to indicate that the subject of crack, although frightening, is not an area of interest for investigations, nor for interventions - neither in terms of prevention, nor of cure.

\section{Final considerations}

In this extensive bibliographical review, a choice was made to include only articles published in Brazilian publications, thus ensuring the review would be systematic. As a result this article has that limitation - non-inclusion of articles published in international journals - which is deemed to be justified by the decision to focus the study on Brazilian publication media, and the advantage of the review being systematic. There are important articles published in international publications which should be the subject of further reviews.

Another product that falls outside the parameters of this article is the Brazilian digital publication 'National Survey on the Use of Crack - Who are the users of crack and/or similar substances in Brazil? How many are there in the Brazilian state capitals? This was coordinated by Francisco Inácio Bastos and Neilane Bertoni, of ICICT/FIOCRUZ, in partnership with the National Drugs Policy Secretariat (Senad). Published in September 2014, it is one of the most complete studies made so far in Brazil on the subject.
As for the 59 articles that are selected here, it was decided to work on them in two ways: The first, descriptive, was a separation of the articles by periodical, field of knowledge, subject area and year of publication; the second, analytical, identified and commented on the debates on the issue of crack.

In the first categorization, it was seen that the field of health was dominant, in that only one article related to the field of social sciences. This reveals an important gap in Brazilian coverage of the subject by disciplines such as sociology and anthropology - which have regularly dealt with subjects intrinsically related to crack, such as violence, the homeless, de-criminalization of drugs, and youth. In terms of a political agenda, this gap might influence decision-makers to work with a sector approach to the detriment of an inter-sector approach.

Within the dominance of coverage from the point of view of health, there is an evident predomination of the sub-categories which can be named 'Psychiatry/psychology' and 'Public health' - these two areas of approach account for almost $70 \%$ of the articles. The output in 'Public health' is concentrated in three periodicals -this is not the case in the other areas, because even in those that have a smaller number of articles, there is a similar or greater diversity (with the exception of a sub-category 'Speech and hearing therapy'). This seems to indicate that although the attention of researchers in public health is aroused by the question of crack, they have less options for publication than the other areas.

As to the subjects of the articles, the predominance of our categories 'Associated risk' and 'Treatment' illustrates the concern with the health problems that crack can directly and indirectly cause, and how to treat them.

A noticeable factor is the small number of articles that aim to study public policies that deal with crack. This could be a reflection of the low output of articles in the ambit of the social sciences, traditionally the science that most analyzes and evaluates public policies, but it also indicates that 'Public health', the field in which analysis and assessment of policies is very present, has dedicated its output in this area to other subjects, especially 'Social relations' and 'Epidemiological profile'.

As well as the low output of articles in the 1990s, there was a hiatus in 2000 and 2001 when no article was published on the subject of crack. Only in 2002 was one article published, indicating that very little was published on the subject 
until well into the first decade of the $21^{\text {st }}$ century: up to 2006 , there were only nine articles.

From 2008 to 2012, however, a further 43 articles were published - almost $73 \%$ of the total with a peak in 2011 and 2012, when 14 and 15 articles were published, respectively. The extremely recent increase in the number of articles is related to the spread of the crack issue over the whole of Brazil, and the response of the federal government to this spread, the Crack - It's Possible to Win Program. It is in this socio-political scenario that there is mobilization among researchers revealing, on one hand, the contemporaneous nature of the problems and, on the other, a certain slowness on the part of the academic community in getting involved with a serious and complex social issue. We include ourselves in this slowness; and we reaffirm that other studies are needed, to make progress on the gaps presented here, especially in studying the question of crack from the point of view of market relationships.

In the second line of categorization - the subjects that are raised for debate - we now seek to highlight the subjects of debate that are identified by this review of Brazilian scientific output, and, in an exercise of advocacy (understood as being to recommend support for specific policy agendas, not necessarily any specific agents), to consider them as political agendas raised by Brazil's academic community, and to postulate their incorporation into the agendas of the managers of public policy.

The first agenda relates to health policy. While the articles point out that the therapeutic communities need to adapt themselves to the parameters and rules of the SUS, they also complain that the mental health services are insufficient and that their network is growing more slowly than the demand.

The second agenda points to overcoming a conception about the crack user: that he/she is condemned to lose his social relationships, and to die, as a result of the drug, in a short period. The articles we have reviewed show that there are some who learn to live with the most damaging effects of the drug, developing strategies that enable them to maintain family and work relationships.

Five political actions identified in the articles derive from this agenda, and at least the first three can be implemented in the short term: (i) investment in research which, taking into ac- count the Brazilian reality and international experience, will generate a better comprehension of the issue of crack; (ii) training and qualification of managers and professionals of the health services who serve crack users, as a way of overcoming prejudices and stigmas; (iii) wide technical debate on the results obtained by the techniques of management of cravings; (iv) adaptation and promotion of the policy of damage reduction; and (v) expansion and qualification of the basic healthcare network, of the Psycho-social Alcohol and Drugs Care Centers (Centros de Atenção Psicossocial Álcool e Drogas - CAPSADs) and of services centering on consumption of crack and other drugs.

The third agenda returns to the idea that the crack user only recognizes life through a nondeath experience, and analyzes that idea from a sociological perspective: public policies need to be more effective in generation of expectations of life and a future for children, adolescents and young people.

The fourth agenda relates to care for the families of crack consumers. This calls for an inter-sector approach. This inter-sector approach, in turn, can be considered as the fifth agenda.

In conclusion, it would be possible to consolidate the five agendas into one single agenda: The public policies on education, health and social assistance need to comply with what the Federal Constitution determines.

For this to happen it is fundamental that there should be acceleration of the growth and improvement of the quality of the public education, health and social assistance systems. For this it is necessary that, like the nation's infrastructure, social protection should be considered as a functional lever for the extinction of poverty and miserable living conditions.

The political agenda could then contain a single approach- which would orient all those that we have presented: the formulation and execution of a Social Wellbeing Growth Acceleration Program: a 'Social Wellbeing PAC', mirroring the government's well-known PAC investment program (Programa de Aceleração de Crescimento, or Growth Acceleration Program) for the country's physical infrastructure. This program would considerably increase the annual rate of state investment in Brazil's public systems of education, health and social assistance. 


\section{Collaborations}

MR Moreira was responsible by preparation, research, methodology and final draft; FMB Fernandes was responsible by preparation and research; JM Ribeiro was responsible by preparation and methodology; and TL Franco Neto was responsible by preparation and revision.

\section{References}

1. Castro MGH. Descentralização e política social no Brasil: as perspectivas dos anos 90. Espaços \& Debates: revista de estudos regionais e urbanos 1991; (32):80-87.

2. Cruz Neto O, Moreira MR, Sucena LFM. Nem Soldados Nem Inocentes: juventude e tráfico de drogas no Rio de Janeiro. Rio de Janeiro: Editora Fiocruz; 2001.

3. Brasil. Programa 'Crack é Possível Vencer' tem adesão de doze estados. [acessado 2012 jul 27]. Disponível em: http://www2.brasil.gov.br/crackepossivelvencer/noticias/programa-crack-e-possivel-vencer-tem-adesaode-dez-estados

4. DSS Brasil: Portal e Observatório sobre iniquidades em Saúde. As cenas do crack, o ajuste de políticas ligadas à droga e os resultados do estudo na visão de seus coordenadores. Entrevista com Neilane Bertoni e Francisco Inácio Bastos. [acessado 2014 out 15]. Disponível em: http://dssbr.org/site/entrevistas/crack-as-cenas-docrack-o-ajuste-de-politicas-ligadas-a-droga-e-o-reconhecimento-das-diferencas-entre-as-regioes-na-visaodos-pesquisadores/

5. Feres Júnior J. O Crack na Grande Mídia. In: Moreira MR, Ribeiro JM, Fernandes FMB, organizadores. A Saúde do Adolescente e do Jovem e suas Interfaces com a Saúde Mental: estudo sobre a questão do Crack - Relatório de Pesquisa. Rio de Janeiro: Fiocruz; 2012.

6. Vaitsman J, Ribeiro JM, Lobato LVC. Análise de políticas, políticas de saúde e a Saúde Coletiva. Physis 2013; 23(2):589-611.

7. Pitta AMF. Um balanço da reforma psiquiátrica: instituições, atores e políticas. Cien Saude Colet 2011; 16(12):4579-4589.

8. Andrade TM. Reflexões sobre políticas de drogas no Brasil. Cien Saude Colet 2011; 16(12):4665-4674.

9. Bastos FI. Crack no Brasil: uma emergência de saúde. Cad Saude Publica 2012; 28(6):1016-1017.

10. Raupp L, Adorno RCF. Circuitos de uso de crack na região central da cidade de São Paulo (SP, Brasil). Cien Saude Colet 2011; 16(5):2613-2622.

11. Oliveira LG, Nappo SA. Crack na cidade São Paulo: acessibilidade, estratégias de mercado e formas de uso. Rev Psiq Clín 2008; 35(6):212-218.

12. Frúgoli Júnior H, Spaggari E. Networks and territorialities: an ethnographic approach to the so-called crackolândia ["crackland"] in São Paulo. Vibrant 2011; 8(2):550-579.

13. Seleghim MR, Marangoni SR, Marcon SS, Oliveira MLF. Vínculo familiar de usuários de crack atendidos em uma unidade de emergência psiquiátrica. Rev. Latino-Am. Enfermagem 2011; 19(5):1163-1170.

14. Mombelli MA, Marcon SS, Costa JB. Caracterização das internações psiquiátricas para desintoxicação de adolescentes dependentes químicos. Rev Bras Enferm 2010; 63(5):735-740.

15. Silva VGB, Soares CB. As mensagens sobre drogas no RAP: como sobreviver na periferia. Cien Saude Colet 2004; 9(4):975-985.

16. Nardi FL, Cunha SM, Bizarro L, Dell'Aglio DD. Drug use and antisocial behavior among adolescents attending public schools in Brazil. Trends Psychiatry Psychother 2012; 34(2):80-86. 
17. Silva Júnior FJG, Monteiro CFS. Os significados da morte e do morrer: a perspectiva de usuários de crack. Rev. Latino-Am. Enfermagem 2012; 20(2):378-383.

18. Ramos SP. O crack, o pai e os psiquiatras e psicanalistas. Rev Psiquiatr RS 2008; 30(2):99-100.

19. Ribeiro LA, Sanchez ZM, Nappo SA. Estratégias desenvolvidas por usuários de crack para lidar com os riscos decorrentes do consumo de droga. J Bras Psiquiatr 2010; 59(3):210-218.

20. Ribeiro M, Dunn J, Sesso R, Dias AC, Laranjeira R. Causes of death among crack cocaine users. Rev Bras Psiquiatr 2006; 28(3):196-202.

21. Oliveira LG, Nappo AS. Caracterização da cultura de crack na cidade de São Paulo: padrão de uso controlado. Rev Saude Publica 2008; 42(4):664-671.

22. Dias AC, Araújo MR, Laranjeira R. Evolução do consumo de crack em coorte com histórico de tratamento. Rev Saude Publica 2011; 45(5):938-948.

23. Sanchez ZVDM, Nappo AS. Sequência de drogas consumidas por usuários de crack e fatores interferentes. Rev Saude Publica 2002; 36(4):420-430.

24. Marques ACPR, Ribeiro M, Laranjeira RR, Andrada NC. Abuso e dependência: crack. Rev Assoc Med Bras 2012; 58(2):141-153.

25. Ferri CP, Laranjeira RR, Silveira DX, Dunn J, Formigoni MLOS. Aumento da procura de tratamento por usuários de crack em dois ambulatórios na cidade de São Paulo, nos anos de 1990 a 1993. Rev Ass Med Brasil 1997; 43(1):25-28.

26. Fiorini JE, Alves AL, Ferreira LR, Fiorini CM, Durães SW, Santos RLD, Nascimento LC, Geraldini AM, Ortiz CF. Use of licit and illicit drugs at the university of alfenas. Rev Hosp Clin Fac Med Sao Paulo 2003; 58(4):199206.

27. Bisch NK, Benchaya MC, Signor L Moleda HMR, Ferigolo M, Andrade TMR, Barros HMT. Aconselhamento telefônico para jovens usuários de crack. Rev Gaúcha Enferm 2011; 32(1):31-39.

28. Zeni TC, Araújo RB. Relação entre o craving por tabaco e o craving por crack em pacientes internados para desintoxicação. J. bras. Psiquiatr 2011; 60(1):28-33.

29. Araujo RB, Castro MGT, Pedroso RS, Santos PL, Leite L, Rocha MR, Marques ACPR. Validação psicométrica do Cocaine Craving Questionnaire-Brief - Versão Brasileira Adaptada para o Crack para dependentes hospitalizados. J Bras Psiquiatr 2011; 60(4):233-239.

30. Chaves TV, Sanchez ZM, Ribeiro LA, Nappo AS. Fissura por crack: comportamentos e estratégias de controle de usuários e ex-usuários. Rev Saude Publica 2011; 45(6):1168-1175.

31. Balbinot AD, Alves GSL, Amaral Junior AF, Araujo RB. Associação entre fissura e perfil antropométrico em dependentes de crack. J Bras Psiquiatr 2011; 60(3):205209.

32. Zeni TC, Araujo RB. O relaxamento respiratório no manejo do craving e dos sintomas de ansiedade em dependentes de crack. Rev Psiquiatr RS 2009; 31(2):116119.
33. Ferreira Filho OF, Turchi MD, Laranjeira R, Castelo A. Perfil sócio-demográfico e de padrões de uso entre dependentes de cocaína hospitalizados. Rev Saude Publica 2003; 37(6):751-759.

34. Dualibi LB, Ribeiro M, Laranjeira R. Profile of cocaine and crack users in Brazil. Cad Saude Publica 2008; 24(Supl. 4):S545-S557.

35. Horta RL, Horta BL, Rosset AP, Horta C. Perfil dos usuários de crack que buscam atendimento em Centros de Atenção Psicossocial. Cad Saude Publica 2011; 27(11):2263-2270.

36. Guimarães CF, Santos DVV, Freitas RC, Araújo RB. Perfil do usuário de crack e fatores relacionados à criminalidade em unidade de internação para desintoxicação no Hospital Psiquiátrico São Pedro de Porto Alegre. Rev PSiquiatr RS 2008; 30(2):101-108.

37. Vargens RW, Cruz MS, Santos MA. Comparação entre usuários de crack e de outras drogas em serviço ambulatorial especializado de hospital universitário. Rev. Latino-Am Enfermagem 2011; 19(N esp):804-812.

38. Pillon SC, Cardoso L, Pereira GAM, Mello E. Perfil dos Idosos Atendidos em um Centro de Atenção Psicossocial - Álcool e Drogas. Esc Anna Nery (impr) 2010; 14(4):742-748.

39. Freire SD, Santos PL, Bortolini M, Moraes JFD, Oliveira MS. Intensidade de uso de crack de acordo com a classe econômica de usuários internados na cidade de Porto Alegre/Brasil. J Bras Psiquiatr 2012; 61(4):221-226.

40. Araujo RB, Balbinot AD, Castro MGT, Rocha MR, Miguel SRPS, Cohen M, Pedroso RS. Tratamento de exposição a estímulos e treinamento de habilidades como coadjuvantes no manejo do craving em um dependente de crack. Trends Psychiatry Psychother 2011; 33(3):181188.

41. Viola TW, Cardoso CO, Francke ID, Gonçalves HA, Pezzi JC, Araújo RB, Fonseca RP, Grassi-Oliveira R. Tomada de decisão em dependentes de crack: um estudo com o Iowa Gambling Task. Estudos de Psicologia 2009; 17(1):99-106

42. Alves GSL, Araujo RB. A utilização dos jogos cooperativos no tratamento de dependentes de crack internados em uma unidade de desintoxicação. Rev Bras Med Esporte 2012; 18(2):77-80.

43. Backes DS, Backes MS, Medeiros HMF, Siqueira DF, Pereira SB, Dalcin CB, Rupolo I. Oficinas de espiritualidade: alternativa de cuidado para o tratamento integral de dependentes químicos. Rev Esc Enferm USP 2012; 46(5):1254-1259.

44. Kessler F, Pechansky F. Uma visão psiquiátrica sobre o fenômeno do crack na atualidade. Rev Psiquiatr RS 2008; 30(2):96-98

45. De Boni R, Pechansky F, Diemen LV, Kessler F, Surrat $\mathrm{H}$, Inciardi J. Diferenças entre fatores de risco para infecção pelo HIV em usuários de drogas injetáveis do Rio de Janeiro e Porto Alegre. Rev. Psiq. Clín. 2005; 32(1):8-9.

46. Azevedo RCS, Botega NJ, Guimarães LAM. Crack users, sexual behaviorandrisk of HIV infection. Rev Bras Psiquiatr 2007; 29(1):39-42. 
47. Malta M, Monteiro S, Lima RMJ, Bauken S, Marco A, Zuim GC, Bastos FI, Singer M, Strathdee SA. HIV/ AIDS. Risk among female sex workers who use crack in Southern, Brazil. Rev Saude Publica 2008; 42(5):830837.

48. Carvalho HB, Seibel SD. Crack cocaine use and its relationship with violence and hiv. Clinics 2009; 64(9):857866.

49. Costa GM, Soibelman M, Zanchet DL, Costa PM, Salgado CAI. Pregnant crack addicts in a psychiatr unit. $J$ Bras Psiquiatr 2012; 61(1):8-12.

50. Nunes CLX, Andrade T, Galvão-Castro B, Bastos FI, Reingold A. Assessing Risk Behaviors and Prevalence of Sexually Transmitted and Blood-Borne Infections among Female Crack Cocaine Users in Salvador Bahia, Brazil. BJID 2007; 11(6):561-566.

51. Scivoletto S, Tsuji RK, Abdo CHN, Queiróz S, Andrade AG, Gattaz WF. Relação entre consumo de drogas e comportamento sexual de estudantes de $2^{\circ}$ grau de São Paulo. Rev Bras Psiquiatr 1999; 21(2):87-94.

52. Cunha PJ, Nicastri S, Gomes LP, Moino RM, Peluso MA. Alterações neuropsicológicas em dependentes de cocaína/crack internados: dados preliminares. Rev Bras Psiquiatr 2004; 26(2):103-106.

53. Gazoni FM, Truffa AAM, Kawamura C, Guimarães HP, Lopes RD, Sandre LV, Lopes AC. Complicações cardiovasculares em usuário de cocaína. Relato de Caso. RBTI 2006; 18(4):427-432.

54. Mançano A, Marchiori E, Zanetti G, Escuissato DL, Duarte BC, Apolinário LA. Complicações pulmonares após uso de crack: achados na tomografia computadorizada de alta resolução do tórax. J Bras Pneumol 2008; 34(5):323-327.

55. Nassif Filho ACN, Bettega SG, Lunedo S, Maestri JE, Gortz F. Repercussões otorrinolaringológicas do abuso de cocaína e/ou crack em dependentes de drogas. Rev Ass Med Brasil 1999; 45(3):237-241.

56. Nigri LF, Samelli AG, Schochat E. Potenciais evocados auditivos de tronco encefálico em usuários de crack e múltiplas drogas. Rev Soc Bras Fonoaudiol 2009; 14(3):528-533.

57. Scheffer M, Pasa GG, Almeida RMM. Dependência de Álcool, Cocaína e Crack e Transtornos Psiquiátricos. Psicologia: Teoria e Pesquisa 2010; 26(3):533-541.
58. Tractenberg SG, Viola TW, Rosa CSO, Donati JM, Francke ID, Pezzi JC, Grassi-Oliveira R. Exposição a trauma e transtorno de estresse pós-traumático em usuárias de crack. J Bras Psiquiatr 2012; 61(4):206-213.

59. Volpe FM, Tavares A, Vargas AP, Rocha PR. Vasculite cerebral e uso de cocaína e crack. Rev Bras Psiquiatr 1999; 21(3):174-176.

60. Gasparin M, Silveira JL, Garcez LW, Levy BS. Comportamento motor oral e global de recém-nascidos de mães usuárias de crack e/ou cocaína. Rev Soc Bras Fonoaudiol 2012; 17(4):459-463.

61. Pechansky F, Kessler FHP, Diemen L, Bumaguin DB, Surrat HL, Inciardi JA. Brazilian female crack users show elevated serum aluminum levels. Rev. Bras. Psiquiatr. 2007; 29(1):39-42.

62. Romanini M, Roso A. Mídia e Crack: Promovendo Saúde ou Reforçando Relações de Dominação? Psicologia: Ciência e Profissão 2012; 32(1):82-97.

63. Santos MFS, Acioli Neto ML, Sousa YSO. Representações sociais do crack na imprensa pernambucana. Estudos de Psicologia 2012; 29(3):379-386.

64. Nappo AS, Sanchez ZM, Ribeiro LA. Is there a crack epidemic among students in Brazil? Comments on media and public health issues. Cad Saude Publica 2012; 28(9):1643-1649.

65. Rodrigues DS, Backes DS, Freitas HMB, Zamberlan C, Gelhen MH, Colomé JS. Conhecimentos produzidos acerca do crack: uma incursão nas dissertações e teses brasileiras. Cien Saude Colet 2012; 17(5):1247-1258.

Article submitted 06/10/2014

Approved 10/18/2014

Final version submitted 10/20/2014 